\title{
WHOSE GOVERNANCE, WHICH LEGITIMACY? MYANMAR'S COLLECTIVE AGENCY IN A DOMINEERING FRAMEWORK ON THE ROHINGYA CRISIS
}

\author{
Kevin Ali Sesarianto \\ Postgraduate Programme, Department of International Relations, Universitas Indonesia; Indonesia; \\ kevin.ali@ui.ac.id
}

\begin{abstract}
Abstrak
Artikel ini bertujuan untuk menjawab pertanyaan sebagai berikut: Mengapa Myanmar menolak intervensi Perserikatan Bangsa-bangsa (PBB) tetapi menerima intervensi Indonesia dalam membahas hal yang sama persis, yakni krisis Rohingya di tahun 2017? Dalam menjawab pertanyaan tersebut, artikel ini menggunakan konsep legitimasi pluralis dengan memperhatikan collective agency dan rasionalitas kolektif dalam kerangka intervensi yang dimaksud. Untuk menggunakan konsep legitimasi pluralis, artikel ini melihat cara yang digunakan kedua aktor tersebut untuk mendeskripsikan Myanmar, terutama melalui kata-kata, baik secara eksklusif atau inklusif. Artikel ini menemukan bahwa PBB merasionalisasi legitimasi intervensinya melalui pewacanaan Myanmar yang menyudutkan dan menjadikannya sebagai liyan sementara Indonesia menghargai subjektivitas Myanmar. Oleh sebab itu, Myanmar tidak melihat intervensi PBB sebagai suatu hal yang dapat disambut. Artikel ini menyimpulkan bahwa keberhasilan suatu kerangka intervensi krisis Rohingya dipengaruhi oleh penghargaan terhadap rasionalitas kolektif Myanmar pada tahap awal.
\end{abstract}

Kata Kunci: Indonesia, interaksi antar-rasionalitas, Myanmar, PBB, rasionalitas kolektif

\begin{abstract}
This article aims to provide an answer to the following question: Why Myanmar rejected the United Nations' intervention whereas it accepted Indonesia's for the same problem, which is the 2017 Rohingya crisis? To answer it and understand the answer, this article utilises the concept of pluralist legitimacy which focuses on collective agency and collective rationality within the intervention framework. In so doing, this article highlights the differing approaches used by the two actors to describe Myanmar within its problem through words in speeches, whether they are exclusionary or inclusionary. This article finds that the United Nations rationalised the legitimacy of its intervention by portraying Myanmar as an on-edge party and, effectively, as Other whereas Indonesia respected Myanmar's subjectivities. Therefore, Myanmar did not consider the United Nations' framework as acceptable. This article concludes that the success of an intervention framework on the Rohingya crisis is influenced by the respect of Myanmar's collective rationality at the initiation stage.
\end{abstract}

Keywords: collective rationality, Indonesia, inter-rationality interaction, Myanmar, United Nations 


\section{Introduction}

The alleviation of the Rohingya crisis in Myanmar, which has resulted in the displacements and deaths of hundreds of thousands of people, has a unique characteristic. An array of interventions have been planned and executed by the international community, including by the United Nations who initiated the Independent International Fact-Finding Mission on Myanmar, but most have been rejected by Myanmar (United Nations, 2017). Indonesia, however, is an anomaly in this case: Indonesia was given access for the first time to visit Myanmar and to meet Aung San Suu Kyi in September 2017 (Associated Press, 2017). Equally an anomaly, although rather normatively, ASEAN as the region's diplomatic backbone has not done any significant measure to alleviate the humanitarian crisis in Myanmar. While this article does not focus on ASEAN's conduct, it is relevant to explain the legitimacy mechanism in the country in particular and in the region in general. This article views Myanmar's different behaviors towards different political entities wishing to intervene in the Rohingya crisis as a problem of support-worthiness stemming from the power relations with respect to an actor's legitimacy (Lenard \& Macdonald, 2019; Macdonald \& Macdonald, 2020). I argue that in order to observe Myanmar's reception (support-worthiness) of a certain working framework (for example the Rohingya 'solution' offered by the UN), we have to analyse how Myanmar's collective agency is treated in that very framework: Is Myanmar treated as a subject or merely an object of the framework? Because the United Nations operates on the doctrine of liberal ethics, especially the responsibility to protect (Nishikawa, 2020) with an internalised value of cosmopolitanism, Myanmar has lost its agency in the intervention. Following it, Myanmar is apathetic towards the United Nations intervention. This article investigates the contrasts between the deletion of Myanmar's collective agency through the United Nations' intervention framework and the consideration of that of Indonesia and several other countries which have worked together.

There have been numerous research findings which address the humanitarian crisis perpetrated by the government of Myanmar to the Rohingya people. Kipgen (2019) and Nishikawa (2020), for example, offer a conflict resolution model in Rohingya which incorporates ethnic sensitivities instead of the ethnic-blind responsibility to protect. Both researchers take into account the nationalist sentiment which plays a significant role in determining the in- and out-group taking hold in this case. The argument is also sustained by Mukherjee (2019), Alam (2019), Sahana, 
Jahangir, and Anisujjaman (2019), and MacLean (2019) who hold that Buddhist identity is deeply embedded in Burmese nationalism tracing back to the colonial days. They suggest that the Rohingya crisis cannot be separated from this sentiment dynamics, which eventually harbours in lopsided racial relations. The researchers also suggest that the disenfranchisement of the Rohingya people is violently reproduced through the displacements and exiles from the Westphalian sovereign borders. Although the mentioned articles satisfactorily explain why the crisis could happen, they fail to explain the refusal of foreign interventions in the Rohingya crisis and the acceptance of Indonesia.

Unlike the previous one, there are only a limited few of articles which explain the perpetuity of the Rohingya crisis despite the supposed 'universality' of human rights. Khan and Ahmed (2019), for example, argue that the humanitarian crisis in Myanmar is prolonged because of the ineffectiveness of the Security Council in which the consensus of the five permanent members is difficult to reach in this matter, if not impossible. Islam (2019), on the other hand, takes into account the domestic political culture which plays a part in the inertia for change in Myanmar, including but not limited to a United Nations intervention. However, the two articles fail to discuss the duality of Myanmar's stance: refusing a United Nations intervention but welcoming Indonesia's. Khan and Ahmed do not take into account the United Nations attempted reach for intervention through the Independent International Fact-Finding Mission on Myanmar and the rejected report from the United Nations Special Rapporteur. That rejection is indicative of the whole body of the United Nations in this conflict, not just the routine report or the Mission. If there is such a rejection towards the United Nations, it is right to assume that military humanitarian interventions, although sanctioned by the Security Council as hinted by the two authors, will not result in a solution. A negative diplomatic response could turn into negative military countermeasures if the initial contact were to be changed from diplomacy to a military action. Islam's article is also not holistic in its approach. On the one hand, it must be said that his approach is not totally wrong in his inquiry on the domestic political culture; on the other hand, however, it is not adequate to explain the aforementioned duality. Therefore, it is required to obtain an understanding of this duality which Myanmar demonstrates in relation to the Rohingya crisis.

Following the inadequacies of previous research, this article argues for a more critical approach to understand Myanmar's response to interventions with respect to the Rohingya crisis. As explained, the inquiries on domestic setting alone and on the United Nations alone are not 
satisfactory. Therefore, this article seeks to combine the two while focusing on an entirely different, though not unaffected by, the two. A more appropriate inquiry, this article holds, is located in the relation between Myanmar and the United Nations, which is affected by the former's domestic political culture and the latter's Western liberal ideology. The interplay between the two surely produces legitimacy requirements. What is legitimacy as perceived by Myanmar? How does the United Nations take those legitimacy requirements into account? To arrive at the answer(s), this article utilizes the concept of non-cosmopolitan legitimacy which considers collective agency as a prerequisite to build sustainable legitimacy. For so long, legitimacy has been defined in a unilateral, unidimensional, and unilinear manner according to Western standards which, in turn, relegate the non-West's collective agency to the level of lesser importance. This article argues that the approach used by the United Nations is too 'infantilizing' (see Epstein, 2012), which gives the impression of underestimating Myanmar's agency. As the result, the approach - more appropriately, the intervention - is not welcome. By contrast, Indonesia's approach is not patronizing. The different receptions are the core of this article.

This article is divided into four sections. The first section discusses the elements of the theory of pluralistic legitimacy and the concept of non-cosmopolitan legitimacy. The section builds the foundation to explain why Myanmar takes issue with the United Nations intervention in the Rohingya crisis. It also discusses the concept of collective agency which affects the supportworthiness of a working framework perceived by an actor, in this case Myanmar on the United Nations intervention framework. The second section discusses the speeches and comments made by relevant actor during the events leading to the attempted intervention in 2017. By contrast, this section also discusses the speeches made by Indonesian officials. To give better understanding, it also takes into account the stances made by Thailand and ASEAN which go hand-in-hand with those of Indonesia. The third section connects the findings to the conceptual framework: How the legitimacy of the United Nations attempted intervention is not regarded well by Myanmar due to the disappearance of Myanmar's collective agency in its framework. The last section concludes the whole article by reasserting that the attempted intervention excludes Myanmar's rationality under the guise of cosmopolitanism whereas Indonesia's intervention is more accommodative of it. 


\section{Pluralistic Legitimacy in a Globalized World}

Acceptance of a working framework (e.g., public policy, intervention, and governance) on the recipient's part depends on the legitimacy retained by that very framework. Discussions on legitimacy have put forward two general models: (1) internationalist, which institutionalizes and formalizes the framework concerning inter-state relations in, ordinarily but not necessarily, international law (Clark, 2005) and (2) cosmopolitan, which takes form abstractly as a global 'state of mind' concerning international standard code of conduct (Cabrera, 2010). In a non-critical discussion, internationalist legitimacy is put into effect when states have agreed on a working framework on a specific issue under an international organization whose auspices overarch the framework. Therefore, following its logical flow, the United Nations has become the highest authority who enjoys absolute legitimacy because of the universal acceptance of its existence given by the whole world. On the other hand, cosmopolitan legitimacy takes root in the assumption that there exist universal values and norms upheld by every agent across the globe. Therefore, working frameworks containing those values are thought to be automatically legitimate for implementation. The problem is that the world does not work that smoothly: Rejections of working frameworks, for example Myanmar's refusal of the United Nations proposed intervention in the Rohingya crisis, take place all over the world. This is puzzling because those frameworks are qualified under the internationalist requirements (they are United Nations frameworks) and the cosmopolitan requirements (they embody and espouse cosmopolitan values). Seeing this puzzle, this author argues for a significant rearrangement of the view on legitimacy.

The problem with the conceptual arrangement of legitimacy as discussed above is its closed rationality. Rationality is defined by Sending and Neumann (2006: 657) as the "systematic thinking and knowledge that is integral to and renders possible different modes of governing". The notion of closed refers to the conception of a political community being limited in its membership or 'citizenship' (see Linklater, 1998) which defines who is included and excluded from the community. The 'closed' notion is also congruent with Anderson's (2006) argument on the imagined constraint of 'horizontal solidarity'. But what does rationality mean? In a political community, there is a collective rationality which is shared by the whole members. According to Macdonald and Macdonald (2020: 526), collective rationality is by nature "“closed', to denote the closure of political contestation around some basic set of common interests or identities, and thus 
the sharing in common of rational criteria for decisive political judgments". Therefore, legitimacy is rooted in the a 'collective rationality' which contains a shared conception of 'common sense' as the result of a shared identity. Cosmopolitanism, a more ambitious vision, assumes that this political closure, including its collective rationality, encompasses the whole world without border. This claim is shocking for the reason that cosmopolitanism has been under fire for its forcibly universalising nature of European particularity (Shapcott, 2008), if not for its racist, civilisationist, anti-Black, and methodologically White nature (see Howell \& Richter-Montpetit, 2019). This universal closure is violent towards rationality differences because it thereby seeks to delete particular collective rationalities.

Emphasis on the concept of collective rationality as explained above is even more relevant due to the inadequacy of the internationalist and cosmopolitan ideologies in reading legitimacy requirements. Macdonald and Macdonald (2020) find that legitimacy according to those two perspectives are too monolithic which put their singular legitimacy requirement in only two aspects: input and output. Input refers to the grounds for the framework; legitimacy requirements in this type include accountability, legality, and representation (Macdonald \& Macdonald, 2020). Output, on the other hand, refers to egalitarian actions in all issues discussed by the working framework (Macdonald \& Macdonald, 2020). However, as has been argued by this section of the article, those two internationalist/cosmopolitan types fail to guarantee legitimacy for the framework which upholds them. What is more important, following Macdonald and Macdonald (2020: 521, original emphasis), is "what kind of reasons count in favour of support". In other words, legitimacy is not determined by transcendental, context-free things such as accountability and egalitarianism. This is in line with the argument that an agent's rationality model, hence its subjective legitimacy requirements, determines the legitimacy (and the rationality) of a framework (see Kaufman, 1997; Sadurski, 2015; Waterman, 1981). It is no exaggeration to claim that legitimacy perception is contingent on the perceiving actor's collective rationality. From the framework's point of view, considerations of the perceiving agent's collective rationality are indicative of the respect for the latter's agency.

Taking in mind the previous discussion, the aim of this article is to understand how Myanmar has rejected the United Nations intervention but welcomed Indonesia in the Rohingya crisis. Taking the conceptual framework into account, this article argues that the duality took place because Myanmar's collective rationality was not appreciated in the United Nations framework; 
therefore, Myanmar lost its agency therein. Myanmar's role in the framework was relegated to only an object of governance despite the difficult cultural dynamics in the crisis. In other words, the framework lacks support-worthiness for Myanmar. Such a condition requires a pluralistic or non-cosmopolitan framework which "allows for many diverse empowered collectives to contribute directly to the legitimacy of global governance institutions, without subordination within the rationalized hierarchies of a unified structure of public rules" (Macdonald \& Macdonald, 2020: 528). Acknowledging that ideal, this author is of the opinion that Myanmar was not treated as the subject of the framework in regard of the Rohingya crisis because Myanmar's collective rationality was subjugated under the United Nations' cosmopolitan rationality. By contrast, this article will argue later, Indonesia did not come with a patronizing rationality; it came with the ethos of pluralistic rationality.

\section{Research Method}

To take the argument further, this article employs discourse analysis. Discourse here is defined in a Lacanian sense, that is, an agent's identification process of a set of rules of the game through words (Epstein, 2010). An agent, in this case a state, identifies itself through words which it adopts from a pool of discourses freely available in the structure. To put in a different light, this method sees that there are 'floating' discourses on matters around the world; when an agent decides to adopt a specific one among others, it begins its identification process. Why is it useful? Understanding an agent's identification process contributes to our understanding of its subject position, that is, the position or the placeholder of a subject in a discourse, including the adopted discourse, relative to the other unadopted discourses on the same issue; and the hierarchical position within the very discourse (see also Epstein, 2010). What is then the difference between that and social identity theory or SIT to determine the identity - and, by extension, the rationality - of an agent through its standing in a social institution (e.g., norms) (Flockhart, 2006)? The difference is located on the oversimplification process done by SIT due to its dogmatic dependence on a hyper-individualized identity, that is, pre-social qualities in an agent which are heavily material and independent of, immune from, and sterile from social interactions and dynamics. Epstein (2010) calls this 'pre-social, whereas an identity is assumed before social interactions, which can be problematic because it also assumes essentialism in social identities. Applied to this article, it is unseemly to assume that Myanmar rejected the United Nations simply because 
Myanmar is what it is without indulging in the dynamics of that stance or position. Therefore, this article takes into account produced narratives, rejected narratives, and adopted narratives to identify Myanmar's collective rationality, the United Nations' conducts, and the resulting rejection.

This article sees discourse as an instrument and evidence of the marginalization of Myanmar's agency in the United Nations working framework. The narratives used by the United Nations to respond to Myanmar's treatment of its interventions were antagonistic to the point that they were perceived as instruments of exclusion by Myanmar. This is evident on the iterative interactions between Myanmar and the United Nations. Needless to say, those iterative interactions are indeed those with two different, oftentimes contradictory, collective rationalities. While those rationalities are equal in content, the subjects of those rationalities have different degrees of power. The United Nations did not just disagree with Myanmar but also, by Western cosmopolitan virtue, subjugated Myanmar. Therefore, Myanmar did not see the framework as support-worthy. This is, by contrast, different from the framework extended by Indonesia who interacts with Myanmar on the same matter; although admittedly Indonesia has rationality similar to that of Myanmar, what is more important is the lack of the United Nations' domineering and disciplining nature.

\section{Myanmar's Rationality and the In/Exclusivity of the Rohingya Intervention Frameworks}

This section provides the evidence that Myanmar's rationality on the Rohingya crisis was subordinated and subjugated by the United Nations in its supervisions and interventions. The previous section reminds us that the United Nations framework does not adhere to the ideal of a pluralistic global governance which rejects any subordination of any collective rationality on any grounds and with any labels. By contrast, Indonesia's framework did not violate the ideal of plurality of collective rationalities, including Myanmar's collective rationality on the Rohingya crisis. This is evident on Myanmar's diverse responses to the two frameworks. To better understand the power dynamics at play, this section provides the chronology of both interventions on the Rohingya crisis.

In 2015, the Myanmar Army incited widespread violence towards the Rohingya people in the state of Rakhine in Myanmar. That series of violence in turn caused massive displacement. In August 2017, the Rohingya people fled their hometown for fear of persecutions with impunity 
exercised by the Myanmar Army with the support of Buddhist extremists (BBC, 2020). The BBC (2020)also reported that there had been widespread crimes against humanity taking the form of sexual violence and rape with the victims disproportionately being women and children. In addition, the military and the police also committed arsons, killings, forced disappearances, and withholding of such basic supplies as food, water, and medicine (Human Rights Watch, 2019).

To give better understanding, the magnitude of the situation, it is important to give the numbers. In 2017, at the beginning of forced displacements, as many as 14,000 Rohingya people were forced to take refuge in Bangladesh with 600,000 people still living in Rakhine with poor quality of life and 4,500 people living at the Myanmar-Bangladesh border under the abuse of the Myanmar Army (Human Rights Watch, 2019). It was also reported that arsons were committed against as many as 392 villages in Rakhine from August 2017 to March 2018 (Human Rights Watch, 2019). The series of violence as described above gives indication on the degree of human rights violations perpetrated by the government of Myanmar.

In response to the violations while bearing in mind the magnitude of the situation, the United Nations established a routine reporting programme on the situation through the UN Special Rapporteur. Needless to say, this framework of intervention was rejected by Myanmar. The Special Rapporteur, Yanghee Lee, claimed that she was disappointed with Myanmar's noncooperation towards her mandate of fact-searching on the Rohingya crisis (Ives, 2017; United Nations, 2017). The non-cooperation in question included Myanmar's refusal to grant permit to Lee which resulted in her inability to directly report the situations in Rakhine on the ground.

It was her words in her last visit to Myanmar in July 2017 that caused withdrawn permits for her further visits which were scheduled to take place in December 2017. On 21 July 2017 in what would become her last visit, Lee wrote on her report that the government of Myanmar "delayed confirming the dates of my visit expecting me to give such an assurance which I found to be an affront to the independence of my mandate as Special Rapporteur" (Lee, 2017). In addition, Lee (2017) also brought up Myanmar's desire to repair its relation with the United Nations, saying: "Before these "special mechanisms" [referring to the United Nations interventions] can be dismantled, Myanmar must first transition into a country that deserves less attention and scrutiny". The first quote shows Lee's reframing of Myanmar's challenge towards the presence of the United Nations into a challenge towards her personal authority and independence. The highlight here is the word independence. The second quote shows that 
Myanmar's agency was at stake. Myanmar could not be considered as a full member of the United Nations (of course normatively) so long as the state did not 'solve' the Rohingya crisis. It hints on the perceived lack of Myanmar's conducts which caused its membership, its position, and its privilege to be reconsidered by the 'society of states' as embodied by the United Nations.

The United Nations also submitted numerous other complaints on the Rohingya crisis. Reuters reported that Lee complained about the state surveillance which ended up with the capture of three human rights activists in Myanmar; Lee also complained when she was denied by the government a meeting with the imprisoned activists (Lewis, 2017). In addition, Lee also summed up failures after failures of the government of Myanmar which had continued to prevail after her previous visit in January 2017 (Lewis, 2017). It is of particular interest and importance that the words that Lee chose at that time to use temporality narrative of 'unchanging conditions' in her speech: Myanmar was still trapped within "old draconian laws that could be amended, reformed, [and] repealed" (United Nations, 2020). These words gain prominent scrutiny in this article because there is a connection between the temporality narrative and the benign coercion exercised by the United Nations. This, however, is a story for the next section.

Indonesia, by contrast, had a different approach. The Indonesian Foreign Minister Retno Marsudi secured a permit to visit Myanmar, unlike the United Nations who had been rejected since July 2017. Marsudi met with the de facto leader Aung San Suu Kyi to discuss Indonesia's concerns in what was called a "4+1 Formula" to tackle the Rohingya crisis. Those four points were (1) restoration of the stability of security in the affected area, (2) abstention from violence, (3) provision of the protection of people in Rakhine regardless of their religious, social, and ethnic backgrounds, and (4) receptive openness towards humanitarian access, with an addition to (5) the implementation of recommendations made by the Advisory Commission for the Rakhine State which was led by Kofi Annan (Mazrieva, 2017). These points were well received by Myanmar. This begs a question: How could Indonesia be well-received while discussing the same issue, both being interventionist to some degree, all of which the United Nations also did, whereas the United Nations was then barred from visiting Myanmar again to act on the same issue? This author argues that it is important to discuss the background for Indonesian interventions in the Rohingya crisis.

Unlike the United Nations, Indonesia did not come to intervene out of the blue. There is a significant historical background which made Indonesia's intervention and, along with an inseparable connection to Thailand and ASEAN, did not violate Myanmar's collective agency. 
Thailand and Indonesia have always been Myanmar's anchor when it comes to humanitarian crises (Parnini, 2013). However, Indonesia and Thailand do not impose an inferior image to Myanmar whenever the latter is experiencing a humanitarian crackdown. This is true for all occasions except one when ASEAN was pushed to be confrontational towards Myanmar after the Asian financial crisis hit at the end of the 1990s (Jones, 2012). However, Jones ${ }^{(2012)}$ also notes that ASEAN member-states always prioritised Myanmar's membership despite mounting pressures from the United States and European countries with one occasion resulting in the refusal to invite ASEAN new members to Asia-Europe Meeting or ASEM. This showcases ASEAN's - and Indonesia's, in particular - support towards Myanmar. The contrast to the United Nations approach lies in the degree of inclusion of Myanmar's agency in its own problem. This is further explained later.

Indonesia's intervention by Thailand's request in the Rohingya crisis was also not such a unilateral case as that by the United Nations or even a simply bilateral one; rather, it was a multilateral initiative. Parnini (2013) claims that Thailand has always been the central help in every episode of Myanmar's humanitarian crisis; the state maintained discussions about the crisis with representatives from a number of other states, including Indonesia. The maintenance of such extensive talks could be attributed to a number of things, including the spirit of equality; however, it could also be attributed to the scarcity of Thailand's ratifications of international human rights legal instruments, such as the Convention Relating to the Status of Refugees, the Convention on the Reduction of Statelessness, and, most importantly, the Genocide Convention. While Indonesia has also not ratified all of them, it has incorporated genocide into its national law under the Human Rights Tribunal Act of 2000. These reasons made Thailand to cede the intervention to Indonesia.

The evidence of the virtue of Thailand's self-restraint is evident on Malaysian failed attempt at an intervention by itself regarding the Rohingya crisis. There are three dimensions of Malaysia's failed attempt First, it was confrontational to the extent that Malaysia labelled Myanmar's actions against the Rohingya people "ethnic cleansing" (Agerholm, 2016; Kwek, 2016). Second, Malaysia's standing with the Genocide Convention is ambivalent as seen on its reservations on retroactive proceedings which were then objected by the Netherlands and the United Kingdom as "incompatible with the object and purpose of the Convention" (United Nations, n.d.). Bearing in mind this fact and the fact that Thailand refused to confront Myanmar for its own lack, Malaysia's interference was hypocritical and, therefore, unwelcome. Last, Malaysia's blunt comment on the Rohingya crisis did not come from genuine concern for reform, 
let alone Malaysia's invitation to include Myanmar's collective rationality for a non-derogatory working framework for the alleviation of the crisis. It came from the then Prime Minister Najib Razak's domestic political campaign to repair his image after it had suffered from the 1Malaysia Development Berhad scandal (Hutt, 2016). The utilization of the Rohingya crisis as a domestic political tool was seen as an insincere gesture by the government of Myanmar.

The stance of ASEAN at that time is also of particular interest. ASEAN was chaired by the Philippines in 2017 during the humanitarian meltdown in the Rakhine state. ASEAN was criticized for not doing any significant measure to alleviate the Rohingya crisis (Muslimin, 2017). However, ASEAN's inactivity was understandable for the reason that the then Chair was experiencing some difficulties with the Moro insurgencies. Human Rights Watch categorizes the response of the government of the Philippines regarding the Moro insurgencies as a human rights violation (Human Rights Watch, 2020). As the Philippines was carrying the burden of the violation label as well, it is understandable that the state did not induce any kind of measure to interfere with the Rohingya crisis.

The examples above can be categorized into three types. The first one is the United Nations model, which assumed its legitimacy automatically because it came as the highest, if the term is appropriate, organization in global politics. The United Nations through its special rapporteur produced aggressive discourses to talk the Rohingya crisis into existence. The second one is the likes of Indonesia, Thailand, and the Philippines. They were mindful of their shortcomings and, therefore, restrained themselves to the bare minimum. They were also aware of the sensitivity on Myanmar's part. The last one is Malaysia. The state interfered with Myanmar with respect to the Rohingya crisis with an ulterior motive. This last category was equally if not more unacceptable to Myanmar.

Legitimacy is a complex formula involving sensitive variables. The above examples have provided proof to incorporate diverse points of view in terms of legitimacy. They highlight that legitimacy cannot be sourced only from the highest body of intergovernmental cooperation. However, this part has not provided why legitimacy cannot be seen in that fashion. For example, this part has discussed that "megaphone diplomacy" is not a desirable means for legitimacy in the Rohingya crisis (The Jakarta Post, 2019); however, it has not discussed why it is undesirable. The next part of this article discusses the findings provided here and the theoretical implications. 


\section{Myanmar's Perception on Support-Worthiness}

As mentioned, this part strings together the findings from the previous part with the conceptual framework on legitimacy. Legitimacy, to remind ourselves, is the support-worthiness of a working framework which holds a specific rationality. Rationality (which is not monolithic however the cosmopolitans would prefer to put it) is a part and also evidence of the inclusion of collective agency, that is, a specific social group's way of thinking of a problem, way to solve it, and the social rituals within the two (Goody, 1993). As such, the Rohingya crisis and the ensuing interventions from the United Nations and from Indonesia are a matter of rationality interactions. What is problematic, however, is the ways which the United Nations employed to enforce a novel rationality towards Myanmar as the sole available working framework to solve the Rohingya crisis. Therefore, due to this enforcement, Myanmar did not regard the framework worthy of support. This part of the article discusses four points which support this argument: (1) the rationality universalization ethos which is (2) used by the United Nations to justify its coercive language towards Myanmar in the Rohingya crisis so that (3) Myanmar's own rationality on the matter is subjugated, deemed archaic and traditional, and deleted through (4) the practices of shaming which hurt Myanmar's collective agency.

The discourse used by the United Nations in regard to the Rohingya crisis was isomorphic to classic Western discourse used to 'punish' the South. This is evident on the United Nations' perception of collective agency in its working framework which stemmed from its own exclusive rationality, that is, the internationalist/cosmopolitan rationality. Curiously, the United Nations human rights investigations into its member states more often than not benefit Western states. For example, when accepting investigation petitions against France for its human rights violations in the Algerian War, the United Nations refused to publicize the content (Duranti, 2020). Moreover, when emerging as a newly independent state, India had to 'prove itself' to be accepted into the United Nations human rights discourse system (R. Khan, 2020). These descriptions show the different and initially incompatible rationality employed by the United Nations is not welcome to accommodate the Third World. Nevertheless, this article has established the conceptual framework of the closedness of a community which is the prerequisite of a shared rationality. Therefore, by extending such a rationality to the Rohingya crisis, the United Nations has forced the universalization of a foreign rationality towards Myanmar (Macdonald \& Macdonald, 2020). The United Nations discourse on Rohingya which cornered Myanmar at global political stage is a set 
of proof which shows the forced incorporation of Myanmar into the prescriptive United Nations rationality. By issuing the 'non-cooperative' label and professing the loss of Myanmar's privilege to associate itself with the international community for as long as Myanmar had not adopted the United Nations framework, the United Nations emphasized the singularity and universality of its framework which applied to every state, including Myanmar. Myanmar's total compliance to the framework is a prerequisite to be admitted into the in-group of the world civilization. As such, the framework was formed at the cost of Myanmar's agency, even in its own problem. One may argue, however, that this is a form of socialization or a form of inter-rationality dialogue. However, a question arises: On what footing did the dialogue occur?

The question on the mode of dialogue between the United Nations and Myanmar is a popular topic in the study of International Relations. Norm socialization, in its abstract form, is a process of compromise between two agents or between an agent and the structure which involves norm introduction from one party to the other and results in shared meaning and intersubjective understanding (Chiu et al., 2010). Therefore, the norm in question is mutually understood through mutual influence by both parties on an equal basis. There are, of course, such elements which can affect the power relations between the socializing parties as military strength, support from international organizations, and other critical elements like race and gender. However, since the United Nations did not begin with the spirit to entertain Myanmar's rationality, equal socialization did not happen. Instead of being equal, the United Nations imposed an essentialist template of norms and conducts on Myanmar. This type of socialization stems from the understanding that a socialization of norms means to replace 'bad norms' with 'good norms'; the good norms in question are associated to what is perceived by the West as 'good', that is, 'progressive' norms, including human rights as a civilizational project with a uniform practice (Epstein, 2012). Therefore, the type of interaction which the United Nations used is not a dialogue on the basis of good faith; it was a coercion which was grounded in the perceived universality of the rationality held by the United Nations. This is evident on the exclusionary discourse already mentioned in the previous section.

This particular perception of support-worthiness projected by Myanmar towards the United Nations could also be justified by observing the measures which the United Nations exercised to ignore, deem obsolete, and delete Myanmar's rationality. By claiming that the cessation of the Rohingya crisis was the only way to have a good relation with the United Nations and, by 
extension, the world civilization in a coercive and exclusivist manner, the United Nations narrowed the source of its legitimacy from solely the cosmopolitan ethics. This is evident on the United Nations' discourse-making emphasis on the statement by the United Nations Special Rapporteur about the requirements for the cessation of several measures for scrutiny, implying that the United Nations assumes automatic legitimacy, as stated in the previous section. Macdonald and Macdonald (2020: 519) remind us that "[t]hey have taken for granted, as normative grounds for legitimacy assessments, some fixed political values developed historically in and for states". The United Nations, in other words, refused to take into account Myanmar's political values because the particular values which the United Nations had incorporated into itself were deemed 'cosmopolitan', meaning that they applied to every agent in the structure of global politics. Furthermore, Macdonald and Macdonald (2020: 520) also support this article's argument that the arrogance (which results in its aggressivity) of the United Nations legitimacy assessment is "grounded in rational forms of collective agency, exercised within 'closed' communities constituted by settled common interests and identities". Even though every political entity has its own rationality, as suggested by this article, the United Nations not only discredited Myanmar's rationality but also judged the latter to suffer from irrationality at all because rationality is only the attribute of the internationalist/cosmopolitan.

Attempts at the deletion of Myanmar's rationality are also shown in the discourse of temporality. For example, the discourse on the dichotomy of backwardness and advancement is used by modernists/civilizationist to bring Myanmar into 'advancement' or to 'modernize'. The basic premise of this politics of telos is the situation in which the agent(s) "allowed themselves to be ruled by custom and tradition and should thus be seen as irrational" (Helliwell \& Hindess, 2013: 74). In regard to legitimacy, a 'modern' cosmopolitan governance assumes automatic authority in order to 'help' bring an otherwise 'backward' agent to the present time, leaving all the 'irrational' rituals behind. Those 'irrational' rituals, while deemed backward by the West, are an integral part of the agent's rationality and, therefore, its collective agency. This discourse enables the United Nations to delete Myanmar's obsolete rationality. In that case, the United Nations mentioned that Myanmar was still trapped in its "old draconian laws" (United Nations, 2020), thereby justifying the coercive discourse. This description highlights the violent deletion of Myanmar's collective agency in its own problem. 
The practice of 'modernizing' in a specific temporality narrative is no more than a show of force on the West's part. As shown, the temporality narrative is not neutral politics; instead, it is associated with derogative condition which merits an external intervention from a more powerful party to change it. It is particularly curious because such politics has become increasingly to engender human rights betterment in the South. Snyder (2020) argues that not only is the practice of human rights shaming ineffective, it also worsens the situation because the agent most likely perceives the practice as an insult from a cultural outsider to the security and autonomy of the group. Translated into the framework utilized by this article, the further the challenge against Myanmar's authority is, the more deviant it will be. At best, the intervention exercised by the United Nations caused Myanmar to resist. At worst, it made the Rohingya situation worse.

Such problematic discourse was absent on Indonesia's intervention. Indonesia came to Myanmar in an advisory capacity. This is the chief reason Indonesia's working framework contained in the points offered by Minister Retno Marsudi during her visit. The efficacy of the working framework notwithstanding, the interaction mode used by Indonesia and Myanmar shows that the incorporation of rationality pluralism (non-cosmopolitan/universal) leads to an intercultural dialogue on an equal footing. The United Nations, by contrast, failed to arrive at that point. This shows that the solution to the Rohingya crisis cannot be initiated by a condescending and exclusivist notion made by the United Nations. To assess the efficacy of whatever framework used by the intervening entity, one needs to establish Myanmar's reception for the intervention framework. While non-Western actors, including ASEAN and its member-states, have been extensively criticized for their lack of efficacy in solving the Rohingya crisis, among other things (Barber \& Teitt, 2020; Chang, 2016), many have failed to take into account the specific legitimacy prerequisite which will determine the support-worthiness of the framework.

This discussion highlights the importance of the other side of an intervention programme: the support-worthiness. The failure of the United Nations intervention framework in the Rohingya crisis indicates the need to take into account Myanmar's agency in the framework. Epstein (2012) reminds any form of hegemonic framework that it cannot infantilize the target inasmuch that it loses its agency. Indonesia's support-worthiness is indicative of the importance of respecting Myanmar's collective rationality to secure the further stages of the intervention framework. 


\section{Conclusion}

This article does not discuss the intervention frameworks on the Rohingya crisis on the merits of their effectivity. Rather, this article highlights the interaction of rationalities between agents as a sensitive yet important foundation of the success of the frameworks. The approach exercised by the United Nations was deemed unworthy of Myanmar's support due to its condescending, infantilizing, civilisationalist nature. It deleted Myanmar's agency. However effective the framework could be, it would not matter because it was rejected in the first place. For that reason, this article concludes that the United Nations needs to reconfigure its procedure to specifically incorporate its member states' unique agencies.

This article also views the strain between the United Nations and Myanmar as the result of failed inter-cultural (also inter-rationality or inter-rituality) interaction. In an inter-rationality interaction, misunderstandings may occur. However, this article concludes that it is more than just a misunderstanding: The United Nations, under the banner of internationalism/cosmopolitanism, assumed automatic legitimacy to lecture and engineer Myanmar's conducts. In this case, the practice of rationality monopoly led to Myanmar's refusal to accept the United Nations. This also highlights the importance of pluralist legitimacy, built on mutual agencies, not on dominations.

The author is also aware that human rights violations are widespread in the postcolonial world (Nair, 2002). However, the domineering and infantilizing practices of the United Nations, as this article has shown, will only lead to a further gap between the West and the East. The incorporation of Myanmar's agency into an international framework to solve the Rohingya crisis will be the first important step.

\section{References}

Agerholm, H. (2016, December 3). Malaysia condemns violence against Rohingya Muslims in Burma as 'ethnic cleansing'. Independent. https://www.independent.co.uk/news/world/asia/malaysia-violence-rohingya-muslimsburma-myanmar-ethnic-cleansing-a7453586.html

Alam, J. (2019). The Current Rohingya Crisis in Myanmar in Historical Perspective. Journal of Muslim Minority Affairs, 39(1), 1-25. https://doi.org/10.1080/13602004.2019.1575560

Anderson, B. (2006). Imagined Communities: Reflections on the Origins and Spread of Nationalism (Revised). Verso.

Associated Press. (2017, September 3). Indonesian minister to raise Rohingya plight with Suu Kyi. Associated Press. 
Barber, R., \& Teitt, S. (2020). The Rohingya Crisis: Can ASEAN Salvage Its Credibility? Survival, 62(5), 41-54. https://doi.org/10.1080/00396338.2020.1819642

BBC. (2020, January 23). Myanmar Rohingya: What you need to know about the crisis. $B B C$. https://www.bbc.com/news/world-asia-41566561

Cabrera, L. (2010). Review article: World government: Renewed debate, persistent challenges. European Journal of International Relations, 16(3), 511-530. https://doi.org/10.1177/1354066109346888

Chang, J. Y. (2016). Essence of security communities: explaining ASEAN. International Relations of the Asia-Pacific, 16(3), 335-369. https://doi.org/10.1093/irap/lcv026

Chiu, C.-Y., Gelfand, M. J., Yamagishi, T., Shteynberg, G., \& Wan, C. (2010). Intersubjective Culture: The Role of Intersubjective Perceptions in Cross-Cultural Research. Perspectives on Psychological Science, 5(4), 482-493. https://doi.org/10.1177/1745691610375562

Clark, I. (2005). Legitimacy in International Society. Oxford University Press.

Duranti, M. (2020). Decolonizing the United Nations: Anti-colonialism and Human Rights in the French Empire. In A. D. Moses, M. Duranti, \& R. Burke (Eds.), Decolonization, SelfDetermination, and the Rise of Global Human Rights Politics (pp. 54-78). Cambridge University Press. https://doi.org/DOI: 10.1017/9781108783170.004

Epstein, C. (2010). Who speaks? Discourse, the subject and the study of identity in international politics. European Journal of International Relations, 17(2), 327-350. https://doi.org/10.1177/1354066109350055

Epstein, C. (2012). Stop Telling Us How to Behave: Socialization or Infantilization?1. International Studies Perspectives, 13(2), 135-145. https://doi.org/10.1111/j.15283585.2012.00458.x

Flockhart, T. (2006). 'Complex Socialization': A Framework for the Study of State Socialization. European Journal of International Relations, 12(1), 89-118. https://doi.org/10.1177/1354066106061331

Goody, J. (1993). East and west: Rationality in review. Ethnos, 58(1-2), 6-36. https://doi.org/10.1080/00141844.1993.9981463

Helliwell, C., \& Hindess, B. (2013). Time and the others. In S. Seth (Ed.), Postcolonial Theory and International Relations: A Critical Introduction. Routledge.

Howell, A., \& Richter-Montpetit, M. (2019). Is securitization theory racist? Civilizationism, methodological whiteness, and antiblack thought in the Copenhagen School. Security Dialogue, 51(1), 3-22. https://doi.org/10.1177/0967010619862921

Human Rights Watch. (2019). Myanmar, Events of 2018. World Report 2019.

Human Rights Watch. (2020, May 22). US: Don't Sell Attack Helicopters to Philippines. Human Rights Watch. https://www.hrw.org/news/2020/05/22/us-dont-sell-attack-helicoptersphilippines

Hutt, D. (2016, December 24). Najib's Dangerous and Self-Serving Rohingya Campaign. The Diplomat. $\quad$ https://thediplomat.com/2016/12/najibs-dangerous-and-self-serving-rohingyacampaign/

Islam, M. S. (2019). Understanding the Rohingya Crisis and the Failure of Human Rights Norm in Myanmar: Possible Policy Responses. Jadavpur Journal of International Relations, 23(2), 158-178. https://doi.org/10.1177/0973598419862482

Ives, M. (2017). Myanmar Vows to Block U.N. Investigators From Entering. New York Times. Jones, L. (2012). ASEAN, Sovereignty and Intervention in Southeast Asia. Palgrave Macmillan. Kaufman, A. (1997). Reason, Self-Legislation and Legitimacy: Conceptions of Freedom in the 
Political Thought of Rousseau and Kant. The Review of Politics, 59(1), 25-52. https://doi.org/DOI: 10.1017/S0034670500027145

Khan, M. T., \& Ahmed, S. (2019). Dealing with the Rohingya crisis: The relevance of the general assembly and R2P. Asian Journal of Comparative Politics, 2057891119868312. https://doi.org/10.1177/2057891119868312

Khan, R. (2020). Between Ambitions and Caution: India, Human Rights, and Self-Determination at the United Nations. In A. D. Moses, M. Duranti, \& R. Burke (Eds.), Decolonization, SelfDetermination, and the Rise of Global Human Rights Politics (pp. 207-235). Cambridge University Press. https://doi.org/DOI: 10.1017/9781108783170.011

Kipgen, N. (2019). The Rohingya Crisis: The Centrality of Identity and Citizenship. Journal of Muslim Minority Affairs, 39(1), 61-74. https://doi.org/10.1080/13602004.2019.1575019

Kwek, T. (2016, December 6). Will Najib's Vocal Defense of the Rohingya Backfire? The Diplomat. https://thediplomat.com/2016/12/will-najibs-vocal-defense-of-the-rohingyabackfire/

Lee, Y. (2017, July 21). End of Mission Statement by Special Rapporteur on the situation of human rights in Myanmar. United Nations Human Rights Office of the High Commissioner. https://www.ohchr.org/en/NewsEvents/Pages/DisplayNews.aspx?NewsID=21900\&LangID $=\mathrm{E}$

Lenard, P. T., \& Macdonald, T. (2019). Democracy versus Security as Standards of Political Legitimacy: The Case of National Policy on Irregular Migrant Arrivals. Perspectives on Politics, 1-17. https://doi.org/DOI: 10.1017/S1537592719003402

Lewis, S. (2017, July 21). U.N. envoy complains of state surveillance, access restrictions in Myanmar. Reuters. https://www.reuters.com/article/us-myanmar-un/u-n-envoy-complainsof-state-surveillance-access-restrictions-in-myanmar-idUSKBN1A61ZR

Linklater, A. (1998). The transformation of political community: ethical foundations of the PostWestphalian era. University of South Carolina Press.

Macdonald, T., \& Macdonald, K. (2020). Towards a 'pluralist' world order: creative agency and legitimacy in global institutions. European Journal of International Relations, 26(2), 518544. https://doi.org/10.1177/1354066119873134

MacLean, K. (2019). The Rohingya Crisis and the Practices of Erasure. Journal of Genocide Research, 21(1), 83-95. https://doi.org/10.1080/14623528.2018.1506628

Mazrieva, E. (2017, September 5). Bantu Atasi Krisis Rohingya, Menlu RI Sampaikan Usul '4+1'. VOA Indonesia. https://www.voaindonesia.com/a/bantu-atasi-krisis-rohingya-menlu-risampaikan-usul-4-1/4014956.html

Mukherjee, K. (2019). The Ethnic Minority Question and Rohingya Crisis in Contemporary Myanmar. Journal of Muslim Minority Affairs, 39(1), 26-43. https://doi.org/10.1080/13602004.2019.1575021

Muslimin, A. S. M. (2017, December 17). ASEAN's Rohingya Response -- Barely A Peep Outside Of Malaysia. Forbes. https://www.forbes.com/sites/anismuslimin/2017/12/17/aseansrohingya-response-barely-a-peep-outside-of-malaysia/\#3cc41bbc39de

Nair, S. (2002). Human Rights and Postcoloniality: Representing Burma. In G. Chowdhry \& S. Nair (Eds.), Power, postcolonialism and international relations: Reading race. Routledge.

Nishikawa, Y. (2020). The Reality of Protecting the Rohingya: An Inherent Limitation of the Responsibility to Protect. Asian Security, 16(1), 90-106. https://doi.org/10.1080/14799855.2018.1547709

Parnini, S. N. (2013). The Crisis of the Rohingya as a Muslim Minority in Myanmar and Bilateral 
Relations with Bangladesh. Journal of Muslim Minority Affairs, 33(2), 281-297. https://doi.org/10.1080/13602004.2013.826453

Sadurski, W. (2015). Supranational public reason: On legitimacy of supranational norm-producing authorities. Global Constitutionalism, 4(3), 396-427. https://doi.org/DOI: 10.1017/S204538171500012X

Sahana, M., Jahangir, S., \& Anisujjaman, M. D. (2019). Forced Migration and the Expatriation of the Rohingya: A Demographic Assessment of Their Historical Exclusions and Statelessness. Journal of Muslim Minority Affairs, 39(1), 44-60. https://doi.org/10.1080/13602004.2019.1587952

Sending, O. J., \& Neumann, I. B. (2006). Governance to Governmentality: Analyzing NGOs, States, and Power. International Studies Quarterly, 50(3), 651-672. https://doi.org/10.1111/j.1468-2478.2006.00418.x

Shapcott, R. (2008). Anti-cosmopolitanism, pluralism and the cosmopolitan harm principle. Review of International Studies, 34(2), 185-205. https://doi.org/DOI: $10.1017 / \mathrm{S} 0260210508007985$

Snyder, J. (2020). Backlash against human rights shaming: emotions in groups. International Theory, 12(1), 109-132. https://doi.org/DOI: 10.1017/S1752971919000216

The Jakarta Post. (2019, December 26). Rules of engagement. The Jakarta Post. https://www.thejakartapost.com/academia/2019/12/26/rules-of-engagement.html

United Nations. (n.d.). Genocide Convention. United Nations Treaty Collection. https://treaties.un.org/pages/ViewDetails.aspx?src=TREATY\&mtdsg_no=IV$1 \&$ chapter=4\&lang=en\#EndDec

United Nations. (2017). UN rights expert 'disappointed' by Myanmar's decision to refuse visit. United Nations News.

United Nations. (2020, March 11). Democracy is sliding away in Myanmar, warns top rights investigator. United Nations News. https://news.un.org/en/story/2020/03/1059181

Waterman, H. (1981). Reasons and Reason: Collective Political Activity in Comparative and Historical Perspective. World Politics, 33(4), 554-589. https://doi.org/DOI: $10.2307 / 2010135$ 